\title{
ПСИХОЛОГІЧНІ ЧИННИКИ ФОРМУВАННЯ КРОС-КУЛЬТУРНОЇ КОМПЕТЕНТНОСТІ СТУДЕНТІВ-ІНОЗЕМЦІВ У ПРОЦЕСІ НАВЧАННЯ УКРАЇНСЬКОЇ МОВИ
}

Бакум 3. П., Пальчикова О. О. Психологічні чинники формування кроскультурної компетентності студентів-іноземців у процесі навчання української мови.

У статті розглянуто психологічні чинники формування крос-культурної компетентності студентів-іноземців у процесі навчання української мови, до яких віднесено країнознавчий інтерес до національного характеру та соціокультурних розбіжностей, а також пізнавальні, професійні та соціальні мотиви.

Ключові слова: крос-культурна компетентність, країнознавчий інтерес, національний характер, соціокультурні розбіжності.

Бакум 3. П., Пальчикова А. А. Психологические факторы формирования кросскультурной компетентности студентов-иностранцев в процессе обучения украинскому языку.

В статье рассмотрены психологические факторы формирования кросс-культурной компетентности студентов-иностранцев в процессе обучения украинскому языку, к которым отнесены интерес к национальному характеру и социокультурным отличиям, а также познавательные, профессиональные и социальные мотивы.

Ключевые слова: кросс-культурная компетентность, страноведческий интерес, национальный характер, социокультурные различия. 
Bakum Z., Palchickova A. Psychological factors of foreign students' cross-cultural competence formation.

The article deals with psychological factors of the formation of foreign students' cross-cultural competence in the process of learning Ukrainian, to which belong such ones as interest to the national character, social and cultural differences, as well as educational, professional and social motives.

Key words: cross-cultural competence, countrystudiesinterest, national character, sociocultural differences.

Успішність засвоєння іноземної мови значною мірою залежить від того, наскільки предметний зміст певної дисципліни відповідає інтересам і потребам студентів. Окреслену тезу підтримує I. Зимня: «Організація навчального матеріалу, використання тих чи тих прийомів, способів, вправ тощо мають переломлюватися крізь призму особистості того, хто навчається, - його потреб, мотивів, активності, інтелекту й інших індивідуально-психологічних особливостей» [3, с. 64]. Водночас російський психолог М. Іванова наголошує на залежності рівня навчальної діяльності студентів ВНЗ від специфіки їх національно-психологічних особливостей. Досліджуючи останню в групах студентів із різною етнічною належністю, науковець виокремлює головні особливості представників африканської, південно-східної азіатської та арабської культур, залежно від яких обирають певні способи педагогічного спілкування. Так, наприклад, африканським студентам притаманні відкритість, комунікативність, схильність до тривожності, обмеження самоконтролю. За наявності набору названих характеристик педагогічному спілкуванню притаманні щирість і м'якість. Під час вербальних контактів не рекомендовано застосовувати демократичний стиль, проте слід приділяти увагу навичкам самоорганізації та дисципліни.

Характерними рисами південно-східних азіатів $є$ розвинуте абстрактне мислення, високий рівень самоконтролю та дисциплінованості, замкнутість, слабка комунікабельність, упертість, спокійне сприйняття змін, спостереження за власною репутацією. Окреслені характеристики потребують упровадження такого педагогічного спілкування, за якого відбувалося б обговорення складних проблем дисципліни, було б можливим ставити запитання для роздумів та активно використовувати самостійні види роботи.

Для студентів арабських країн Близького Сходу типовими психологічними особливостями $є$ щирість, інтерес до встановлення контактів, відсутність страху перед критикою, недисциплінованість, роздратованість, конфліктність, тому упродовж педагогічної взаємодії доцільно акцентувати на дискусії під час навчання. У процесі спілкування слід дотримуватися спокою й делікатності, розвивати в них навички самодисципліни [4].

Отже, знання психологічних основ впливає на вибір підходів, методів і засобів на певному етапі навчання та сприяє перетворенню

(ㄱ 3. П. Бакум, О. О. Пальчикова, 2013. - $655-$ 
навчального матеріалу на мовленнєву модель у практичній діяльності.

Нині до психологічних чинників, що впливають на оволодіння іноземними студентами соціокультурним матеріалом, науковці (О. Бутирська, С. Григорян, Б. Додонов, Д. Кікнадзе, О. Леонтьєв, Г. Маслікова, Г. Щукіна та ін.) відносять інтереси та мотиви діяльності суб’єктів навчання.

У загальнопсихологічному розумінні «інтерес» витлумачують як емоційне переживання пізнавальної потреби. У своєму дослідженні погодимося 3 позицією Г. Щукіної, на думку якої окреслене поняття є вибірковою спрямованістю психічних процесів особистості на об'єкти i предмети довкілля [16].

Навчання іноземної мови важко уявити без розвитку пізнавального інтересу, що передбачає зацікавленість до процесу пізнання, змісту i способів отримання знань. Вищерозглянутий термін можна визначити як орієнтацію особистості, звернену до царини пізнання, їі предметного аспекту й самого процесу оволодіння професією. Дослідниця наголошує на тому, що пізнавальний інтерес є завжди свідомим мотивом, тому виявити і керувати ним достатньо легко [16]. Загальним твердженням можна вважати те, що наявність таких інтересів супроводжується підвищенням пізнавальної активності студентства, у процесі якої представники іншомовної аудиторії ознайомлюються з відомостями про історію, культуру, мистецтва, звичаї, традиції, устрій, життєві погляди, переконання, форми проведення дозвілля, захоплення носіїв, - тобто ті факти про чужу країну, що зацікавлюють студента та надають змогу вивчати мову не лише через механічне заучування граматичної будови і шаблонів мовлення, а й через асоціативне й образне мислення, апелюючи до відомостей з історичного та культурного минулого. Із позиції крос-культурного підходу до навчання української мови як іноземної, доцільно виокремити ті психологічні чинники формування крос-культурної компетентності, у яких було б зроблено акцент на культурні відмінності та можливі негативні наслідки в разі виникнення непорозумінь. На наш погляд, таким рушієм можна вважати країнознавчі інтереси, 3-поміж яких виокремимо інтерес до пізнання національного характеру українців та виявлення соціокультурних розбіжностей.

Р. Гришкова зауважує, що з історичної позиції національний менталітет $\epsilon$ результатом залежності духовної спадщини покоління від умов довкілля. Так, під впливом кліматичних, соціальних, економічних, політичних умов формується своєрідність народу, виокремлюються ті риси та звички, що є притаманними окремій нації, за якими одних представників легко відрізнити від інших. До складу таких якостей науковець відносить обряди й ритуали, норми повсякденної поведінки, мову тіла [2]. Після проведення дослідження з виявлення впливу рівня соціокультурного розвитку етносів на їх політичне життя, вдалося визначити характерні риси, притаманні національному характеру українського народу: 
- перевага в суспільстві «жіночого характеру», для якого традиційними $\epsilon$ потяг до сім'ї, установлення дружніх відносин, що часто $\epsilon$ причиною перенесення бізнес-контактів у площину особистих;

- бажання прислухатися до інтересів колективу й слідувати його настановам;

- прагнення обійти ризик та уникнути невизначеності, бути максимально впевненим у правильності вибору під час прийняття рішення;

- заохочення до культу дитячої тотальної слухняності (батьки контролюють дії своїх нащадків з дитинства до вступу в доросле життя) [2].

Унаслідок виявлення окреслених якостей робимо висновки про те, що українцям складно проявляти ініціативу, швидко зреагувати в нетипових умовах, спонтанно обрати стратегію в нестандартних ситуаціях.

Як уже зазначалося вище, однією з принципових засад крос-культурного навчання $є$ визнання представниками обох культур наявності соціокультурних розбіжностей, які можна легко простежити у веденні способу життя, обрядах, моделях поведінки, способах вербального та невербального спілкування. Так, однією з найпоширеніших соціокультурних розбіжностей вважають обряд укладання шлюбу. Зіставляючи спосіб життя народів Європи, Північної Америки, Азї та Африки, О. Садохін виокремив такі відмінності: якщо представники європейської та північноамериканської культур самостійно обирають собі пару, то більшість репрезентантів Азії та Африки не мають такого права: питання вступу до шлюбу часто розв'язують їх батьки, при чому майбутньому подружжю заборонено бачитися до весілля [12].

Інший приклад черпаємо 3 дослідження М. Казанджиєвої, яка проаналізувала відмінності в системі цінностей іноземного студентства. Порівнюючи ціннісні орієнтації українських та іноземних студентів, науковець визначила, що для перших превалюючими є цінності кар'єри, до складу яких відносять гарну освіту, самовдосконалення, цікаву роботу та гедонічні (отримання насолоди від задоволення фізіологічних потреб). Натомість у представників Сходу перше місце посідають філософські цінності: свобода, життєва мудрість, пізнання нового, тоді як на другий план виходять альтруїстичні (відповідальність, прагнення допомогти) [6]. Таку невідповідність у соціокультурній царині можна пояснити несхожістю національного характеру, релігійних вірувань, колективістськими та індивідуалістськими настановами.

Нині більшість науковців (Н. Бабич, В. Бойко, Є. Верещагін, В. Гак, Л. Даниленко, В. Костомаров, А. Семотюк, В. Ужченко та ін.) погоджується 3 тим, що найбільш яскраво відмінності в соціокультурному середовищі віддзеркалено у мові, а саме на їі лексико-семантичному рівні, ядром якого вважають фразеологічний пласт.

У сучасній лінгводидактиці панує думка про фразеологічний рівень мови, який найбільш чітко й прозоро відбиває іï національно-культурну () 3. П. Бакум, О. О. Пальчикова, 2013. - -657- 
семантику, вказує на невідповідність культурних і мовних картин світу, втілених у лексиці різних мов. Як зазначала В. Телія, фразеологічний шар мови - дзеркало, у якому відображається національна свідомість лінгвокультурної спільності. Саме завдяки культурно-національному забарвленню лексичного значення фразеологізмів відбувається відтворення буденного менталітету народу [13]. 3 одного боку, насиченість фразеологізмів лінгвокраїнознавчою інформацією зацікавлює аудиторію, урізноманітнює навчальний матеріал, спонукає до пізнання історії та культури країни, мова якої вивчається, з іншого - часткова еквівалентність або безеквівалентність фразеологічних одиниць під час перекладу створює нездоланні бар'єри адекватного сприйняття інформації. Є. Верещагін та В. Костомаров зауважували: «Дві національні культури ніколи не збігаються повністю, це випливає 3 того, що кожна складається з національних та інтернаціональних елементів. Сукупності схожих (інтернаціональних) і відмінних (національних) одиниць для кожної пари зіставних культур будуть різними... Тому не дивно, що доводиться витрачати час та енергію на засвоєння не лише плану вираження певного мовного явища, а й плану змісту, тобто треба формувати у свідомості тих, хто навчається, поняття про нові предмети і явища, що не мають аналогів ні в їх рідній культурі, ні в рідній мові» [14, с. 30].

Яскравим прикладом окресленого твердження слугує невідповідність фразеологізмів із зоонімічним компонентом у різних мовах. Так, говорячи про такі людські риси, як неквапливість, загальмованість, українцю та росіянину одразу ж спаде на думку образ черепахи та відповідні порівняння людини з нею: рос. черепаший шаг, укр. Повільний, як черепаха. Натомість, у Китаї зазначена тварина символізує боягузтво, невпевненість, бажання відсторонитися від справ. Тому, коли в Китаї говорять черепаха, яка ховає голову, маючи на увазі людину, що задкує назад, пасує перед труднощами, в Росії про таких осіб кажуть рак пятится назад, а в Україні - моя хата скраю - нічого не знаю [15]. Наведені приклади доводять, що нетотожність перекладу фразеологізмів у різних мовах є наслідком неоднакового сприйняття дійсності та за відсутності лінгвокраїнознавчих знань призводить до зіткнення культур: представникам доводиться долати перешкоди розуміння культурного змісту інформації, що стоїть за мовною формою його вираження.

Отже, лексико-семантичний рівень $є$ ключовим у перетині культур: 3 одного боку, він відкриває прихований зміст мови, яка вивчається (за допомогою слів, виразів, зворотів передається культурний світ народу, комунікант збагачується країнознавчими знаннями), 3 іншого, розбіжності в семантичному наповненні мовних форм спонукають до зіставлення рідної та нерідної мов, занурюють суб'єкта в пізнання власної мови, іiі історії, культурного розвитку. Знання ідіоматичних виразів, фразеологічних зворотів, прислів'їв та приказок дозволяє дослідити зміни як у самій структурі мові, так і в соціально-історичному житті їі народу, 
пізнати властиве йому світовідчуття, сприйняття та світобачення, на основі чого складається певне уявлення про ту чи ту етнічну групу.

Безперечно, ознайомлення із соціокультурними особливостями українського народу позитивно впливає на засвоєння мови: відомості про історію, географічне розташування, економічний розвиток, побут заохочують до комунікації та сприяють засвоєнню мовного матеріалу у стислі строки. Однак для реалізації крос-культурного підходу до навчання української мови як іноземної важливо знати не лише який саме лінгвокраїнознавчий матеріал викликає інтерес в іншомовної аудиторії, доцільно також виявити, чому він $є$ цікавим та у зв'язку з цим виокремити мотиви студентів.

У психологічних дослідженнях $є$ кілька поглядів на визначення терміна «мотив». Так, С. Рубінштейн зауважував, що підгрунтям будь-якої дії $\epsilon$ мотив - переживання чогось важливого, що спонукає до активності та надає їй важливості [11]. В. Мерлін під мотивами розуміє психічні умови та якості особистості, що позначають вузьке, приватне та мінливе ставлення суб' єкта до певних явищ і предметів дійсності [9]. Згідно з поглядами О. Леонтьєва, «мотив» $\epsilon$ специфічним видом внутрішньої спонукальної діяльності, «опредмеченою», «об’ єктивованою потребою». «Оскільки потреба знаходить у предметі свою визначеність, окреслений предмет стає мотивом діяльності, тим, що спонукає ії» [7, с. 312]. Відповідно, мотив-причина діяльності виконує функцію рушія та скеровує дії особистості.

Для нашого дослідження актуальною $є$ дефініція, запропонована I. Зимньою, яка у психології навчання російської мови в іншомовній аудиторії визначила мотив як явище, що пояснює специфіку мовленнєвої дії [3]. Узагальнюючи експериментальні дослідження мотивів, проведені Л. Божович, П. Гальперіним, Д. Ельконіним, О. Леонтьєвим, А. Марковою, В. Мерліним, Ю. Пассовим, С. Рубінштейном, Н. Симоновою, П. Якобсоном та ін., можна стверджувати, що в навчанні мов превалюють три основні категорії мотивів - пізнавальні, професійні та соціальні.

Особливість першої групи полягає в тому, що мотиви, які входять до ii складу, віддзеркалюють прагнення особистості здобути знання про країну, мова якої вивчається із загальноосвітньою метою; спрямовані на реалізацію особистісного потенціалу. Під час їх усвідомлення особистість проявляє жагу до пізнання, прагнення розширити світогляд, поглибити та систематизувати знання. Окреслена група мотивів співвідноситься 3 пізнавальною та інтелектуальною потребою людини, при чому передостанній, 3 погляду Л. Божович, властивий позитивний емоційний тон і ненасиченість [5]. Відомий російський психолог І. Зимня зазначає: «Керуючись подібними мотивами, не враховуючи втому та інші чинники, що відволікають, студент наполегливо та захоплено працює над навчальним матеріалом, точніше над розв'язанням навчальних завдань» [3, с. 101].

Беручи до уваги класифікації, подані В. Давидовим, Л. Ітельсоном, (ㄱ 3. П. Бакум, О. О. Пальчикова, 2013. - -659- 
А. Марковою, А. Петровським, Г. Щукіною, виокремимо низку пізнавальних мотивів у межах навчання української мови іноземних студентів.

1. Широкі пізнавальні - зорієнтовані на оволодіння новими знаннями; пов'язані зі змістом навчальної діяльності та процесом іiі виконання. Вони визначаються глибиною інтересу до знань, який може проявлятися; особливостей мовної системи, політичних, економічних, культурних аспектів життя України та ін. До цієї групи, на наш погляд, варто залучити: а) бажання пізнати нові факти та цікаві явища, що фігурують в отриманій інформації; б) прагнення осягнути невидиму глибинну сутність якостей предметів.

Г. Щукіна зазначала, що останній пункт передбачає пошук, здогадки, активне послуговування набутими знаннями. Покликаючись на погляди вищезгаданого психолога, уважаємо, що в лінгвістичному аспекті на цьому рівні пізнавальної активності студента-іноземця може цікавити механізм побудови усного й писемного висловлювання українською мовою. На цій стадії суб'єкти навчання вже володіють елементарним багажем знань, проте недостатнім для вільного оперування ними в усному та писемному мовленні.

2. Навчально-пізнавальні - спрямовані на засвоєння засобів здобуття знань. До цієї групи А. Маркова відносить інтереси до прийомів самостійного набуття досвіду, методів наукового пізнання, способів саморегуляції навчальної роботи [8]. Розширимо межі зазначеної групи та додамо: прагнення виявити закономірності мовних явищ під час опрацювання навчального матеріалу; бажання оволодіти достатнім рівнем фонетичного, лексичного, граматичного мінімуму задля розуміння та відтворення інформації у межах міжпредметного циклу та побутового спілкування.

У психологічній літературі вказано, що поряд із пізнавальними мотивами однією 3 умов успішного засвоєння матеріалу $\epsilon$ також урахування професійних мотивів навчальної діяльності, що в розумінні Н. Бакшаєвої та А. Вербицького, спонукають суб'єкта до вдосконалення власної діяльності - іiі способів, засобів, форм, методів, тощо [1, с. 46].

Аналізуючи професійну діяльність суб'єкта, науковці визначили такі види мотивів: теоретичне осмислення основ професійної діяльності; професійний зріст, саморозвиток; покликання до професії; самореалізація; співробітництво з колегами; удосконалення діяльності; відповідальність за результати професійної діяльності; прагматичні (престиж, заробітна плата, кар'єра) [1].

Згідно 3 поданою класифікацією припустимо наявність таких професійних мотивів, якими керуються студенти-іноземці під час навчання української мови:

- бажання отримати знання з української мови та культури задля підготовки до обраної професії; 
- прагнення використати набутий мовний та культурний досвід у майбутній професії;

- спрямованість на засвоєння екстралінгвістичної країнознавчо цінної інформації задля установлення контактів у діловому спілкуванні.

3-тя велика група мотивів - соціальні. У дослідженні, проведеному А. Ніколаєвою, постають як рушійна сила мовленнєвої діяльності, основою яких є: 1) позитивні емоції (згідно з позицією Д. Ельконіна, залучає дружню атмосферу, цікавість); 2) внутрішній душевний стан, бажання самовиразитися, обмін враженнями, показ своїх здібностей, таланту; 3) внутрішня і зовнішня активність особистості; 4) толерантність до інших мов; 5) потреба у спілкуванні, усвідомлення мети навчання сьогодні та в майбутньому [10].

Беручи до уваги класифікацію, подану Л. Благонадьожиною, Л. Божович, А. Марковою, Г. Щукіною, П. Якобсоном та ін., виокремимо такі групи соціальних мотивів у навчанні іноземців української мови, як: а) широкі соціальні; б) вузькосоціальні; в) мотиви соціального співробітництва.

До першої групи відносять ті мотиви, що залучають розуміння необхідності навчання задля розширення світогляду, самовдосконалення, розвитку почуття відповідальності. На думку Л. Божович, їх сутність полягає в тому, щоб спонукати особистість до діяльності через свідомо задану мету та прийняття рішень. 3 одного боку, суб'єкти навчання не розглядають названі мотиви як свій суспільний обов'язок, форму участі в суспільній праці; з іншого, - ставляться до них як до засобу отримати в майбутньому вигідну роботу та забезпечити свій матеріальний добробут. 3 огляду на це соціальні мотиви можуть втілювати як суспільні потреби особистості, так і індивідуальні спонукання, що, у свою чергу, визначає моральний вигляд студента [5]. Щодо соціальних мотивів студентаіноземця, то вважаємо за доцільне виокремити такі:

- бажання добре підготуватися до обраної професії;

- розуміння важливості навчання мови задля результативного співробітництва з представниками іншої культури;

- намагання утвердити свій соціальний статус у суспільстві через учіння.

До вузькосоціальних мотивів слід віднести прагнення посісти певне місце у стосунках з оточенням, отримати його підтримку та схвалення; заслужити авторитет у суспільстві; отримати винагороду за працю.

Мотиви соціального співробітництва спрямовані на створення та зміцнення міжособистісних контактів. Сюди варто залучити усвідомлення й аналіз форм свого співробітництва і взаємин між представниками рідного та іноземного суспільства, їх постійне вдосконалення; закріплення власної ролі в групі / колективі чи суспільстві загалом).

На наш погляд, вищезазначену групу мотивів не можна вважати самодостатньою без урахування комунікативної підгрупи, до якої віднесемо:

(ㄱ 3. П. Бакум, О. О. Пальчикова, 2013. - -661- 
- необхідність у побутовому та професійному спілкуванні з носіями;

- прагнення підтримувати зв'язок із однолітками та співробітниками;

- збагачення словникового запасу задля вдалого ведення переговорів;

- важливість адекватного розуміння отриманої інформації;

- потреба в доборі мовних засобів відповідних до ситуації спілкування задля усунення культурних непорозумінь і конфліктів.

Узагальнюючи результати дослідження з виявлення психологічних чинників формування крос-культурної компетентності в іноземних студентів у процесі навчання української мови, виокремимо країнознавчий інтерес до пізнання національного характеру та виявлення соціокультурних розбіжностей як той, що скеровує навчальну діяльність на встановлення та розвиток соціокультурних зв'язків між представниками різних країн через оволодіння знаннями про подібні та відмінні характеристики в українській та іноземній мові та культури; також пізнавальні, професійні та соціальні мотиви як спонуки до засвоєння необхідних знань, умінь і навичок, необхідних для оперування мовним і країнознавчим матеріалом.

\section{Література}

1. Бакшаева Н. А. Психология мотивации студентов : [учебное пособие] / Н. А. Бакшаева, А. А. Вербицкий. - М. : Логос, 2006. - 184 с.

2. Гришкова Р. О. Формування іншомовної соціокультурної компетенції студентів нефілологічних спеціальностей : [монографія] / Р. О. Гришкова. - Миколаїв : Вид-во МДГУ ім. Петра Могили, 2007. - 424 с.

3. Зимняя И. А. Психология обучения иностранным языкам в школе / Ирина Алексеевна Зимняя. - М. : Просвещение, 1991. - 221 с.

4. Иванова М. И. Социально-психологическая адаптация иностранных студентов к высшей школе России : дис. ... д-ра психол. наук : 19.00.05 / М. А. Иванова. - СПб., 2001. $-353 \mathrm{c}$.

5. Изучение мотивации поведения детей и подростков : сб. эксперим. исслед. / ред. Л. И. Божович, Л. В. Благонадежина. - Москва : Педагогика, 1972. - 352 с.

6. Казанджиєва М. С. Ціннісні орієнтації сучасної студентської молоді як основа діалогу культур / М. С. Казанджиєва // Актуальні проблеми навчання іноземних студентів на сучасному етапі : матеріали міжнар. наук.-практ. семінару. - Суми : Сумський державний університет, 2012. - С. 105-110.

7. Леонтьев А. Н. Проблемы развития психики / А. Н. Леонтьев. - М. : Изд-во МГУ, 1981. - [4-е изд.]. -584 с.

8. Маркова А. К. Формирование мотивации учения в школьном возрасте / А. К. Маркова. - М. : Просвещение, 1983. - 96 с.

9. Мерлин В. С. Лекции по психологии мотивов человека : нервно-психическое напряжение / В. С. Мерлин // Хрестоматия по психологии : [учебное пособие] / сост. В. В. Мироненко ; ред. А. В. Петровский. - М. : Просвещение, 1977. - С. 298-304.

10. Николаева А. Н. Индивидуальный подход в обучении неродным языкам (психолого-методический аспект) : дис. ... канд. пед. наук : 13. 00. 02 / А. М. Николаева. M., 1999. - $191 \mathrm{c}$.

11. Рубинштейн С. Л. Проблемы общей психологи / С. Л. Рубинштейн. - М. : Педагогика, 1973. - 424 с. 
12. Садохин А. П. Межкультурная коммуникация : [учебное пособие] / А. П. Садохин. М. : Альфа-М; ИНФРА-М, 2004. - 288 с.

13. Телия В. Н. Русская фразеология. Семантический, прагматический и лингвокультурологический аспекты / В. Н. Телия. - М. : Школа «Языки русской культуры», 1996. - 288 с.

14. Тер-Минасова С. Г. Язык и межкультурная коммуникация : [учебное пособие] / С. Г. Тер-Минасова. - М. : Слово / Slovo, 2008. - 624 с.

15. Фразеологічний словник української мови / [уклад. : В. М. Білоноженко та ін.]. К. : «Наукова думка», 1993. - 984 с.

16. Щукина Г. И. Проблема познавательного интереса в педагогике / Г. И. Щукина. - М. : Педагогика, 1971. - 351 с. 